\title{
EVALUATING THE NEXUS BETWEEN FINANCIAL DEEPENING AND ECONOMIC GROWTH: EVIDENCE FROM UKRAINE
}

\section{Iryna Kondrat, Olha Kots}

Lviv Polytechnic National University, Lviv, Ukraine

e-mails: Iryna.Y.Kondrat@1pnu.ua; Olha.O.Kots@lpnu.ua

(C) 2018 Iryna Kondrat, Olha Kots

This is an open access article distributed under the Creative Commons Attribution-NonCommercial-NoDerivs license (http://creativecommons.org/licenses/by-nc-nd/3.0/)

DOI: 10.15611/fins.2018.1.04

JEL Classification: E44, G10, G22

\begin{abstract}
In this paper systemic problems of Ukrainian banking sector are reviewed and the solutions are offered. The main objective of the study is to examine the relationship between a financial deepening and economic growth in Ukraine by estimating several multiple regression models over the 1993 to 2015 period. A real GDP growth per capita was used as an indicator for the economic growth. The domestic credit to private sector (\% of GDP) was used as an index of financial depth. The study concludes that financial deepening causes a slight impact on the economic growth of Ukraine. A low level of impact is an indicator of a limitedness of lending to the real economy. This means that banking sector has not become the real driving force of the economic growth in Ukraine yet. The study suggests a statement that policy makers should design the policies which will encourage lending especially high tech production, small and mid-size business, micro financing to the real economy to promote economic growth and increase employment.
\end{abstract}

Keywords: financial deepening, economic growth, banking sector, multiple regression analysis.

\section{Introduction}

Since 1991, the formation and development of Ukrainian financial market has taken place on the basis of a bank centered model, which means that the main financial flows were formed through banking institutions. As compared to other segments of the financial market, banking system was growing at a faster rate, and dominated them. Therefore, the banking crisis in 2013-2014 provoked an extensive economic crisis in the country. Since 2014, a restructurisation of Ukrainian banking system, the withdrawal of insolvent banks out of the market, and the increase of reserves for active operations etc. has been going on.

Systemic problems of Ukrainian banking sector include:

1. Shortage of long-term resources (resources with terms of repayment that exceed 5 years). This deprives the banking system of its investment lender properties. 
2. Banking system's failure to function as the main creditor for the strategic economic restructurisation, substitution of import, and the development of industry, small and mid-size business. In most cases Ukrainian banking system aims at providing a service to ongoing billing needs of economic subjects and short-term needs in working capital.

Ukrainian banking system is characterized by sizeable profit of liquidity, which is evidence of non-effective management of money supply, and liquidity of banking system within monetary policy of the National Bank of Ukraine. In 2015, banks placed their funds in certificates of deposit of the National Bank of Ukraine to the amount of 2.8 trillion hryvnias that exceeds a nominal GDP up to one and half times. As long as interest rate for certificate of deposit of the National Bank of Ukraine is almost equal to the interest rate of the household subject of credits in hryvnias, it has significantly limited interbank lending and lending to the real economy, deepening the recession.

3. Disparity of banking balance (maturity mismatch) is a discrepancy between short-term bank liabilities and longer-term lending. In a stable macroeconomic situation, a systematic risk caused by the disparity of banking balance stays hidden, and in case of macroeconomic uncertainty, which is accompanied by an outflow of deposits, it is abruptly actualized and results in a chain reaction of escalation of the banking crisis.

4. Disparity of banking balance by currency (currency mismatch) is a discrepancy between the lending currency and the currency in which the borrower receives income for its repayment. This creates a systematic vulnerability of the banking sector and its clients to currency risks: in the case of the devaluation of hryvnia; it leads to insolvency of borrowers, the growth of distressed assets, and transforms into banks' problems with the repayment of currency deposits.

5. Regulatory risk is based on the need of legislative regulating the issue of foreign currency credits to individuals, restructuring debts of legal entities, and protecting the rights of lenders.

The withdrawal of banks from the market in most cases creates the precedents of ownership right infringement. According to Article 13 of the Constitution of Ukraine, the state protects the rights of all subjects of ownership and disposal rights, while the Law of Ukraine "On the system of deposit insurance of legal entities" limited warranty of returning of allocated funds in case of insolvency of banks exclusively in the amount of 200,000 hryvnias to individuals. All other claims of creditors on the insolvent bank are met in order of priority at the value of property of the bank, and in case of insufficiency of property are considered to be repaid. Therefore, claims of individuals (fourth-priority creditors), legal entities and sole proprietors (seventh-priority creditors) on amount that exceeds 200,000 hryvnias are not met in general, so it leads to failure to meet liabilities to counterparts, officers, state etc., and forces the bankruptcy of individuals. 
6. Low level of customer confidence in the banking system is due to bankruptcy of bank, and the inability to refund all investing.

7. Since 2005 the occurrence of banks with foreign capital to Ukraine has not eased the structural problems of the economy, but increased them. The involvement of external lending resources and the intensive growth of consumer lending did not lead to the development of domestic industry and the internal market. Instead, it was directed to finance the import of goods of the end use, therefore developing economies of industrial countries. Consumer lending over 2005 to 2008 period resulted in the critical growth of external corporate bank debt and worsening of the disparities of the current account of payment balance (from 2.5 billion dollars surplus in 2005 to 12.8 billion dollars deficit in 2008) and currency and financial crisis after an outflow of capital (sudden stop effect).

Due to poor banking oversight and a significant part of foreign currency credits during the crisis in 2008-2009, poor quality bank assets have grown significantly.

Over 2015 the volume of distressed credits increased to 119.4 billion hryvnias or $47.62 \%$ and on 01.01 .2016 it was equal to 370 billion hryvnias. Part of distressed credits in credit portfolio increased from $18.98 \%$ on 01.01 .2015 to $28.03 \%$ on 01.01.2016. Due to devaluation of hryvnia, credit balance provided by individuals and legal entities in foreign currency and expressed in hryvnias has increased, which caused a negative impact on the quality of credit portfolio and an urge of specific allocations to reserves, and led to the increase of unprofitability of banking system.

8. Structure of the banking market based on bank size becomes more homogeneous, which increases systematic risk: over two years the share of small banks (which assets share is less than $0.5 \%$ of banking system assets share) has decreased from $13 \%$ to $6 \%$ in the statutory capital of the banking system and large banks (which assets share is higher than $0.5 \%$ of banking system assets share) has increased from $58 \%$ to $75 \%$. At the same time, there was a decrease in large banks' share in the total equity of the banking system, mainly through the pending loss formed by this group, that was equal to 102.93 billion hryvnias.

In the structure of banks' asset allocation over 2014 to 2015 period a substantial growth of asset shares of large banks (78\% of total assets) occurred. Meanwhile, there was a decrease of assets of small banks, which is usually related to the withdrawal from the banking market. Thus, the concentration increases, and the competition decreases in the banking market. During the last two years Herfindahl-Hirschman Index has doubled to 850-950 units (for comparison, in Germany and France it is equal to 400 units).

The withdrawal of banking institutions from the market resulted in the decrease of capital amount of the banking system: from 192.6 billions hryvnias at the beginning of 2014 to 104 billion hryvnias at the beginning of 2016 .

In 2014 new requirements on the minimal amount of authorized capital of a bank came into effect. At the moment of a registration of a legal entity that has intention to engage in banking activities, it cannot be lower than 500 million hryvnias. 
In order to improve the financial stability of the Ukrainian banking system and protect the interests of creditors and investors of banks, Resolution No. 58 of the Board of the National Bank of Ukraine "On increasing the banks' capital" of 04.02.2016 obliges banks, which authorized capital does not meet the requirements, to increase it to 500 million hryvnias until 11.07.2024.

Such requirements do not match those of EU and European Council Directives and are much more difficult. This can lead to regulatory arbitrage and capital outflow from Ukraine.

9. Since the beginning of 2014, the positive trend of the lending increment volume in the economy has changed to the negative one. By the end of 2015, the ratio of credits to GDP, that is financial depth of the economy, is less than $56.97 \%$ and is continuously decreasing. This figure is well over for other countries: Denmark $-180 \%$, Japan $-187 \%$, most EU members - over $100 \%$ on average, and countries with the biggest revenues - over $150 \%$.

According to National Bank of Ukraine, increasing capital requirements of banks should lead to the increment of lending amount, financial depth of economy, and economic growth in Ukraine.

The main objective of the study is to examine the relationship between financial deepening and economic growth in Ukraine by estimating several multiple regression models over the 1993 to 2015 period. We are going to carry out empirical testing hypotheses about the impact of the financial depth of the economy of Ukraine on its economic growth.

\section{Literature review}

The problem of the financial impact on the economic growth has been discussed in the literature for a long period. This idea was contributed in 1873 by Bagehot, who believed that the industrial revolution in England had been caused by financial markets. Further theoretical and empirical studies identified followers and skeptics on the financial impact on the economic growth. Schumpeter believed that economic growth cannot take place without financial resources which must be provided by banks. He argued that "credit impacts the distribution of income, whilst bank credit specifically enhances flows or circulations of capital resources which then is used for productivity and innovation" [Schumpeter 1911].

Goldsmith concluded that overall financial development tends to accelerate economic growth, facilitate new company formation, ease company access to external financing, and boost company growth [Goldsmith 1969].

King and Levine demonstrated that "a more-developed financial system fosters productivity improvement by choosing higher quality entrepreneurs and projects, by more effectively mobilizing external financing for these entrepreneurs, by providing superior vehicles for diversifying the risk of innovative activities, and by revealing more accurately the potentially large profits associated with the uncertain business 
of innovation. In these ways, better financial systems stimulate economic growth by accelerating the rate of productivity enhancement" [King, Levine 1993].

Levine suggested that financial intermediaries may influence savings and investment decisions and hence economic growth by the "(I) production of ex ante information about possible investments, (II) monitoring of investments and implementation of corporate governance, (III) trading, diversification, and management of risk, (IV) mobilization and pooling of savings, and (V) exchange of goods and services." The results of empirical analyses, including company-level studies, industry-level studies, individual country-studies, time-series studies, panelinvestigations, and broad cross-country comparisons, demonstrate a strong positive link between the functioning of the financial system and long-run economic growth [Levine 2005].

Other economists believed that the role of finance is not of crucial importance to the economic growth [Meier, Seers 1984]. Nobel Laureate Robert Lucas dismisses finance as an "over-stressed" determinant of economic growth [Lucas 1988]. Joan Robinson argued that "where enterprise leads finance follows". Therefore, finance does not cause economic growth. Finance responds to changing demands from the "real sector" [Robinson 1952].

Financial systems in emerging markets are well below the levels reached in advanced economies. Berglöf and Bolton summarized "weak evidence at best of a link between financial development (as measured by the domestic credit to GDP ratio) and growth [...] Ukraine and many other countries that were formerly part of the Soviet Union saw neither financial development nor economic growth. Again, the link between financial development and economic growth does not appear to be very strong during the first decade of transition" [Berglöf, Bolton 2002].

Caporale et al. investigated the relationship between financial development and economic growth in ten new EU members by estimating a dynamic panel data model over 1994 to 2007 period. Financial depth is found to be lacking in all these countries with only a minor positive effect of some indicators of financial development. But banking sector is found to have accelerated the growth [Caporale et al. 2009].

Some domestic scientists studied the impact of the growth of the loan portfolio of Ukrainian banks on the economy. G. Azarenkova concluded that the growth rate of lending to individuals exceeded the rate of increase in corporate lending. Consequently, the credit expansion was not directed to the real economy. However, loans granted to legal entities from 2009 to 2014 decreased. Such dynamics are negative for the economy as a whole, as evidenced by the "isolation" of the banking sector from the reality [Azarenkova, Olefir 2015].

Slav'yuk et al. emphasized that the main reason of financial market imbalances in Ukraine lies in the fact that financial intermediaries do not perform their functions of transforming the savings into real investments. Their operations have mainly speculative nature, and a high level of risk, and do not impact significantly the dynamics of GDP [Slav'yuk et al. 2017]. 


\section{Data, methodology, analysis and results}

Levine suggested following possible indicators for the economic growth: real GDP growth per capita, average capital stock growth per capita and productivity growth. In the study a real GDP growth per capita will be used [Levine 1997].

Shaw defined financial deepening as the process of accumulation of financial assets at a faster pace than the accumulation of non-financial wealth. He argued that financial deepening occurs when financial assets grow faster than income [Shaw 1973].

For our purpose we use the domestic credit to private sector (DC) (\% of GDP) as an index of financial depth. Other variables that influence real GDP growth per capita $\left(G \_\right.$realGDP) are: real GNI growth per capita $\left(G_{-}\right.$realGNI) $(\%)$; gross capital formation $(G C F)$ ( $\%$ of GDP); trade (T) (\% of GDP); inflation in consumer prices (Infl) (annual \%); general government final consumption expenditure (GFCE) (\% of GDP); gross enrolment ratio, secondary, both sexes (GER) (\%); market capitalization of listed companies (MC) (\% of GDP); net incurrence of liabilities, domestic (NIL_d) ( $\%$ of GDP); net incurrence of liabilities, foreign (NIL $f$ ) ( $\%$ of GDP); reform index of financial institutional development (FID) (\%); interest rate spread (IRS) (lending rate minus deposit rate, $\%$ ).

In this study the secondary data obtained from the State Statistics Service of Ukraine and the World Bank Open Data are used. The time series data cover the period from 1993 to 2015.

To evaluate the relationship between financial deepening and economic growth the following models are proposed:

$$
\begin{aligned}
& G \_ \text {realGDP }=a+b_{1} G \_ \text {realGNI }+b_{2} G C F+b_{3} T+b_{4} I n f l+b_{5} G F C E+ \\
& +b_{6} G E R+b_{7} D C+b_{8} M C+b_{9} N I L \_d+b_{10} N I L_{-} f+b_{11} F I D+b_{12} I R S+\varepsilon,
\end{aligned}
$$

where $a, b$-regression parameters; $\varepsilon$ - error.

A sample for modeling the relationship between economic growth and financial development through regression model is formed according to data for Ukraine over 1993 to 2015 period at 1 year interval (Table 5 in Appendix).

Accordingly, 23 observations were conducted. The sample is representative. The results of regression statistics of the relationship between economic growth and financial development indices calculated by means of MS Excel software package are presented in Table 1.

The first index, which is the most important when analyzing regression, is a Multiple $\mathrm{R}$ that shows the dependence of the dependent variable on explanatory. In this case its value is 0.95 , so it can be stated that there is a direct linear relationship between economic growth and financial development of Ukraine. The value of $\mathrm{R}$ Square is 0.903 , so it can be stated that a reliability of the resulting regression model ( $90.3 \%$ of cases are described through the proposed regression model) exists. 
Table 1. Results of regression statistics of the relationship between economic growth and financial development indices calculated by means of MS Excel software package

\begin{tabular}{|l|c|}
\hline \multicolumn{1}{|c|}{ Indices } & Value \\
\hline Multiple R & 0.950 \\
\hline R Square & 0.903 \\
\hline Adjusted R Square & 0.786 \\
\hline Standard Error & 10.012 \\
\hline Observations & 23.00 \\
\hline F-stat & 7.73 \\
\hline F-stat (necessary tabular value) & 2.91 \\
\hline Durbin Watson (DW) & 1.97 \\
\hline
\end{tabular}

Source: calculated by the authors.

Adjusted R Square is 0.786 . This means that new variables, which are introduced into the model, will not cause a significant impact on this model.

F-stat, which indicates the importance and reliability of the model in this case is 7.73 , and its necessary tabular value is 2.91 . Thus, actual value of index is bigger than tabular one that shows the importance of model and the reliability of hypothesis about the existence of the relationship between the economic growth and the financial development in Ukraine.

Autocorrelations between the residues of a regression model were not found: calculated Durbin Watson (DW) statistics for this model is 1.97, which corresponds to the condition $1.5<\mathrm{DW}<2.5$, whereby residual autocorrelation is absent.

Regression model of the relationship between the indices of the economic growth and financial development for Ukraine is:

$$
\begin{aligned}
& G \_r e a l G D P=-134.528+0.929 G \_r e a l G N I+2.403 G C F+0.749 T \\
& +0.004 I n f l+2.334 G F C E-0.457 G E R-0.383 D C+0.018 M C+ \\
& +1.814 N I L \_d-0.084 N I L \_f+10.129 F I D-0.526 I R S+\varepsilon .
\end{aligned}
$$

In order to detect impact forces of different model parameters on resulting indices we will calculate correlation indices of dependent and independent variables of regression model of the relationship between the economic growth and the financial development for Ukraine (Table 6 in Appendix).

According to the results of correlations of dependent and independent variables, it can be concluded that all model parameters have an impact on resulting index. A positive impact on a real GDP growth per capita in Ukraine causes the following variables: real GNI growth per capita, gross capital formation (\% of GDP), trade (\% of GDP), gross enrolment ratio, secondary, both sexes (\%), domestic credit to private sector ( $\%$ of GDP), market capitalization of listed companies (\% of GDP), 
reform index of financial institutional development (\%). The main positive impact causes real GNI growth per capita (\%). Meanwhile, a negative one on a real GDP growth per capita in Ukraine causes inflation in consumer prices (annual \%), general government final consumption expenditure (\% of GDP), net incurrence of liabilities, domestic ( $\%$ of GDP), net incurrence of liabilities, foreign ( $\%$ of GDP), interest rate spread (lending rate minus deposit rate, \%). The main negative impact causes net incurrence of liabilities, foreign ( $\%$ of GDP).

According to correlation matrix, domestic credit to private sector causes an impact on a real GDP per capita growth by 0,084 . That means that in case of the increase of domestic credit to private sector, the value of real GDP growth per capita with probability of $8.4 \%$ will also increase.

Financial deepening, which is displayed by the index of domestic credit to private sector (\% of GDP) in the model, causes a slight positive impact on the economic development of Ukraine, which was measured by the indicator of real GDP growth per capita. This means that the development of lending leads to the economic growth in Ukraine, but the slight impact of the independent variable on the dependent one is an indicator of not enough developed lending, limitation of its amount for the real economy. The main factors that hinder the development of lending in Ukraine are: for individuals - inflation and low income level, and for legal entities - high interest rates and unfavorable market conditions. Another problem of development of lending in Ukraine is the targeted use of credit resources. The basis is lending current objectives and needs (consumer lending, credits for working capital), and for the economic growth of the state a strategic investments in the development of manufacture, infrastructure etc. is necessary now.

Let us consider analogic regression model of the relationship between the economic growth and the financial development for Ukraine on condition that gross enrolment ratio, secondary, both sexes (\%), will not be taken into consideration, which reaches maximum value for Ukraine during the analyzed period, and enlarge by summing up net incurrence of liabilities, domestic (\% of GDP), net incurrence of liabilities, foreign (\% of GDP) into one index:

$$
L L=N I L_{-} d+N I L_{-} f,
$$

where $L$ is liquid liabilities ( $\%$ of GDP).

The regression model takes the following form:

$$
\begin{aligned}
& G_{-} \text {realGDP }=a+b_{1} G_{-} \text {realGNI }+b_{2} G C F+b_{3} T+b_{4} I n f l+b_{5} G F C E+ \\
& +b_{7} D C+b_{8} M C+b_{13} L L+b_{11} F I D+b_{12} I R S+\varepsilon .
\end{aligned}
$$

The results of regression statistics of the relationship between the economic growth and financial development indices calculated by means of MS Excel software package are presented in Table 2. 
Table 2. Results of regression statistics of the relationship between the economic growth and financial development indices calculated by means of MS Excel software package

\begin{tabular}{|l|c|}
\hline \multicolumn{1}{|c|}{ Indices } & Value \\
\hline Multiple R & 0.948 \\
\hline R Square & 0.899 \\
\hline Adjusted R Square & 0.816 \\
\hline Standard Error & 9.287 \\
\hline Observations & 23 \\
\hline F-stat & 10.740 \\
\hline F-stat (necessary tabular value) & 2.850 \\
\hline Durbin Watson (DW) & 2.090 \\
\hline
\end{tabular}

Source: calculated by the authors.

23 observations were conducted. Multiple $\mathrm{R}$ is 0.948 , so it can be stated that there is a direct linear relationship between the economic growth and the financial development of Ukraine. The value of R Square is 0.899 . Resulting regression model is reliable ( $89.9 \%$ of cases are described through the proposed regression model). Adjusted R Square is 0.816 . This means that new variables, which are introduced into the model, will not cause a significant impact on this model.

F-stat, which indicates the importance and reliability of the model, in this case is 10.74 , and its necessary tabular value is 2.85 . Actual value of index is bigger than tabular one that shows the importance of model and the reliability of hypothesis about the existence of the relationship between the economic growth and the financial development in Ukraine.

Autocorrelations between residues of a regression model were not found: calculated Durbin Watson (DW) statistics for this model is 2.09, which corresponds to the condition $1.5<\mathrm{DW}<2.5$, whereby residual autocorrelation is absent.

Regression model of the relationship between indices of the economic growth and the financial development for Ukraine takes the following form:

$$
\begin{aligned}
& G_{-} \text {realGDP }=-191.176+0.965 G \_ \text {real } G N I+2.665 G C F+0.674 T+ \\
& +0.004 I n f l+2.476 G F C E-0.424 D C+0.003 M C+1.565 L L+ \\
& +14.059 F I D-0.434 I R S+\varepsilon .
\end{aligned}
$$

In order to detect impact forces of different model parameters on resulting index we will calculate correlation indices of dependent and independent variables of regression model of the relationship between economic growth and financial development for Ukraine (Table 7 in Appendix).

According to the results of dependent and independent variables of correlation, it can be concluded that all model parameters cause an impact on resulting index. 
Comparing to previous regression model, the correlation of dependent and independent variables has not changed.

Let us analyze the relationship between volumes of real GDP per capita (\$) and domestic credit to private sector (\% of GDP) of Ukraine. Output data for the analysis are presented in Table 3.

Table 3. Data on real GDP per capita (\$) and domestic credit to private sector (\% of GDP) of Ukraine during 1992-2015 years

\begin{tabular}{|l|c|c|}
\hline Years & Real GDP per capita $(\$)$ & Domestic credit to private sector (\% of GDP) \\
\hline 1993 & $1,258.136$ & 1.421 \\
\hline 1994 & $1,011.986$ & 4.625 \\
\hline 1995 & 935.985 & 1.475 \\
\hline 1996 & 872.709 & 1.385 \\
\hline 1997 & 991.230 & 2.457 \\
\hline 1998 & 835.260 & 7.824 \\
\hline 1999 & 635.773 & 8.586 \\
\hline 2000 & 635.713 & 11.169 \\
\hline 2001 & 780.738 & 13.030 \\
\hline 2002 & 879.475 & 17.655 \\
\hline 2003 & $1,048.522$ & 24.584 \\
\hline 2004 & $1,367.352$ & 25.167 \\
\hline 2005 & $1,828.718$ & 32.197 \\
\hline 2006 & $2,303.019$ & 44.363 \\
\hline 2007 & $3,068.609$ & 58.170 \\
\hline 2008 & $3,891.038$ & 88.378 \\
\hline 2009 & $2,545.480$ & 90.573 \\
\hline 2010 & $2,973.996$ & 78.412 \\
\hline 2011 & $3,569.757$ & 71.075 \\
\hline 2012 & $3,855.421$ & 69.579 \\
\hline 2013 & $3,986.283$ & 74.264 \\
\hline 2014 & $3,065.164$ & 76.198 \\
\hline 2015 & $2,114.955$ & 56.969 \\
\hline & & \\
\hline & & \\
\hline
\end{tabular}

Source: calculated by the authors according to [http://data.worldbank.org; https://bank.gov.ua].

Correlation between real GDP per capita (\$) and domestic credit to private sector (\% of GDP) of Ukraine is 0.918 , so it can be stated that there is a tight positive linear relationship between parameters.

Let us consider the following regression model:

$$
\text { real_GDP }=a+b D C+\varepsilon,
$$


where real_GDP is real per capita GDP (\$); DC is domestic credit to private sector (\% of GDP).

The results of indices of regression statistics of the relationship between real GDP per capita (\$) and domestic credit to private sector (\% of GDP) calculated by means of MS Excel program package are presented in Table 4.

Table 4. Results of indices of regression statistics of the relationship between real GDP per capita (\$) and domestic credit to private sector (\% of GDP) calculated by means of MS Excel program package

\begin{tabular}{|l|c|}
\hline \multicolumn{1}{|c|}{ Indices } & Value \\
\hline Multiple R & 0.918 \\
\hline R Square & 0.843 \\
\hline Adjusted R Square & 0.836 \\
\hline Standard Error & 481.662 \\
\hline Observations & 23 \\
\hline F-stat & 112.86 \\
\hline F-stat (necessary tabular value) & 4.3 \\
\hline Durbin Watson (DW) & 1.05 \\
\hline
\end{tabular}

Source: calculated by the authors.

23 observations were conducted. Multiple R is 0.918 , so it can be stated that there is a direct linear relationship between GDP per capita (\$) and domestic credit to private sector (\% of GDP). The value of R Square is 0.843 . Resulting regression model is reliable $(84.3 \%$ of cases are described through the proposed regression model). Adjusted R Square is 0.836. This means that new variables, which are introduced into the model, will not cause a significant impact on this model.

F-stat, which indicates the importance and reliability of the model, in this case is 112.86 , and its necessary tabular value is 4.3 . Actual value of index is bigger than tabular one that shows the importance of model and the reliability of hypothesis about the existence of the relationship between real GDP per capita (\$) and domestic credit to private sector (\% of GDP) for Ukraine. Regression model of the relationship between the indices of the economic growth and the financial development for Ukraine takes the following form:

$$
\text { real_GDP }=669.1432+33.814 D C+\varepsilon \text {. }
$$

According to model parameters, in case of increase of financial depth of economy of Ukraine by $1 \%$, the value of real GDP per capita will increase by $33.814 \$$. the existence of autocorrelation at the level of 0.918 means that there is a strong positive impact of independent variable on dependant one, so the increase of financial depth by 1 item causes a relevant increase of GDP per capita with the probability of $91.8 \%$. 
Autocorrelation between residues of a regression model was found: calculated Durbin Watson (DW) for this model is 1.05 , which does not correspond to the condition $1.5<\mathrm{DW}<2.5$, according to which residual autocorrelation is absent.

The existence of residual autocorrelation means that a new independent variable must be introduced into the model.

All the models are created with the reliability of $95 \%$.

\section{Conclusions}

According to the results of modeling of the relationship between real GDP per capita and domestic credit to private sector for Ukraine, it can be concluded that the increase in the financial depth of the economy will cause economic growth. However, the impact of financial deepening is slight. Low level of impact is an indicator of the limitation of lending volume to the real economy. This means that the banking sector has not become a real driving force of the economic growth in Ukraine yet. That is why for GDP growth and GDP growth per capita it is necessary to develop the lending, stimulate long-term financing of investment projects aimed at innovative companies upgrade, expand and improve the quality of products produced by them, and create infrastructure as a basis of enterprises functioning etc.

The main function of the banking system needs to be the optimal redistribution of capital in the economy for financing intensive sustainable economic growth on the basis of high tech industrialization, infrastructure development, science, education, and general welfare of the population. For this, the following is necessary:

- Encourage lending micro financing to the real economy, especially high tech production, small and mid-size business, to promote economic growth and increase employment. For this purpose, it is important to develop medium-term instruments and models for refinancing transparent and stable Ukrainian banks to increase their credit portfolio to enterprises of the real sector (funding for lending scheme).

- Regulate the requirements of the National Bank of Ukraine when it comes to the minimum amount of authorized capital according to the European directives. The minimum amount of a universal bank capital is 150 million hryvnias (5 million Euro).

- Take into account the world experience, create a clear and transparent mechanism for managing distressed bank assets.

- Restore the confidence of investors and encourage the inflow of deposits.

- Strengthen the protection of the rights of creditors in the liquidation of banks. 


\section{References}

Azarenkova G., Olefir Y., 2015, Assessment of the influence crisis of 2008-2009 on the banking system of Ukraine, European cooperation, Warsaw, pp. 36-43.

Berglöf E., Bolton P., 2002, The great divide and beyond: Financial architecture in transition, The Journal of Economic Perspectives, no. 16 (1), pp. 77-100.

Caporale G.M., Rault C., Sova R., Sova A., 2009, Financial development and economic growth: Evidence from ten new EU members, Discussion papers, http://www.diw.de/english/products/publications/discussion_papers/27539.html.

Goldsmith R.W., 1969, Financial Structure and Development, Yale University Press, New Haven.

https://bank.gov.ua.

http://data.worldbank.org. https://bank.gov.ua.

http://ebrd.com.

http://ukrstat.gov.ua.

http://tradingeconomics.com.

King R.G., Levine R., 1993, Finance, entrepreneurship and growth: Theory and evidence, Journal of Monetary Economics, no. 32(3), pp. 513-542.

Levine R., 1997, Financial development and economic growth: Views and agenda, Journal of Economic Literature, no. 35(2), pp. 688-726.

Levine R., 2005, Finance and growth: Theory and evidence, handbook of economic growth, [in:] Aghion P., Durlauf S. (eds.), edition 1, vol. 1, pp. 865-934.

Lucas R.E., 1988, On the mechanics of economic development, Journal of Monetary Economics, No. 22(1), pp. 3-42.

Meier G.M., Seers D., 1984, Pioneers in Development, World Bank, Washington D.C.

Robinson J., 1952, The Generalization of the General Theory, [in:] The Rate of Interest and Other Essays, Macmillan, London, pp. 69-142.

Schumpeter J., 1911, The Theory of Economic Development, (reprinted 1969), Oxford University Press, Oxford.

Shaw E.S., 1973, Financial Deepening in Economic Development, Oxford University Press, New York. Slav'yuk R., Shkvarchuk L., Kondrat I., 2017, Financial market imbalance: reasons and peculiarities of occurrence in Ukraine, Investment Management and Financial Innovations, no. 14(1-1), pp. 227-235.

\section{OCENA RELACJI MIĘDZY POGŁĘBIANIEM SIĘ RYNKU FINANSOWEGO I WZROSTEM GOSPODARCZYM: DOWODY Z UKRAINY}

Streszczenie: W niniejszej pracy sprawdzamy systemowe problemy ukraińskiego sektora bankowego i oferujemy rozwiązania. Głównym celem badania jest analiza relacji między pogłębianiem się rynku finansowego i wzrostem gospodarczym na Ukrainie poprzez oszacowanie kilku modeli regresji wielokrotnej z okresu od 1993 do 2015 roku. Jako wskaźnik wzrostu gospodarczego był wykorzystywany wzrost realnego PKB per capita. Kredyt wewnętrzny dla sektora prywatnego (\% PKB) był stosowany jako miara głębokości rynku finansowego. W badaniu stwierdzono, że pogłębianie się rynku finansowego powoduje nieznaczny wpływ na wzrost gospodarczy Ukrainy. Niski poziom oddziaływania jest wskaźnikiem ograniczoności kredytowej sektora realnego. Oznacza to, że sektor bankowy jeszcze nie stał się realną siłą napędową wzrostu gospodarczego na Ukrainie. W badaniu sugeruje się twierdzenie, że decydenci powinni zaprojektować politykę, która będzie zachęcać do kredytowania realnej gospodarki, zwłaszcza produkcji wysokich technologii, małych i średniej wielkości firm, jak również do mikrofinansowania na rzecz wzrostu gospodarczego i zwiększenia zatrudnienia.

Słowa kluczowe: pogłębianie się rynku finansowego, wzrost gospodarczy, sektor bankowy, analiza regresji wielokrotnej. 
APPENDIX

Table 5. Output data for Ukraine to create a regression model

\begin{tabular}{|c|c|c|c|c|c|c|c|c|c|c|c|c|c|}
\hline Years & G_realGDP & G_realGNI & $G C F$ & $T$ & Infl & GFCE & GER & $D C$ & $M C$ & $N I L \_d$ & $N I L \_f$ & $F I D$ & $I R S$ \\
\hline 1993 & -11.266 & -13.380 & 36.293 & 52.069 & 4734.914 & 15.983 & 89.849 & 1.421 & 2.300 & 0.699 & 1.935 & 1.000 & 35.617 \\
\hline 1994 & -19.565 & -17.886 & 35.331 & 73.944 & 891.188 & 19.362 & 89.778 & 4.625 & 1.400 & 0.442 & 1.706 & 1.000 & 41.658 \\
\hline 1995 & -7.510 & -8.911 & 26.683 & 97.230 & 376.746 & 21.270 & 89.560 & 1.475 & 6.200 & 0.184 & 1.477 & 2.000 & 52.408 \\
\hline 1996 & -6.760 & -6.522 & 22.671 & 93.857 & 80.326 & 21.759 & 88.250 & 1.385 & 7.300 & 0.073 & 1.248 & 2.000 & 46.250 \\
\hline 1997 & 13.581 & 3.488 & 21.446 & 84.241 & 15.941 & 27.399 & 89.120 & 2.457 & 9.000 & 0.331 & 1.019 & 2.000 & 30.908 \\
\hline 1998 & -15.735 & -4.494 & 20.817 & 86.050 & 10.577 & 24.608 & 94.470 & 7.824 & 1.500 & 0.589 & 0.791 & 1.670 & 32.243 \\
\hline 1999 & -23.883 & -10.588 & 17.513 & 101.952 & 22.684 & 19.830 & 101.426 & 8.586 & 3.400 & 2.090 & -0.063 & 2.000 & 34.253 \\
\hline 2000 & -0.009 & -7.895 & 19.630 & 119.858 & 28.203 & 20.918 & 103.804 & 11.169 & 7.000 & 1.484 & -0.344 & 2.000 & 27.811 \\
\hline 2001 & 22.813 & 4.286 & 21.764 & 109.295 & 11.959 & 19.622 & 105.416 & 13.030 & 3.600 & 1.289 & 0.290 & 2.000 & 21.289 \\
\hline 2002 & 12.647 & 8.219 & 20.149 & 105.794 & 0.757 & 18.396 & 106.170 & 17.655 & 8.600 & 0.413 & -0.414 & 2.330 & 17.423 \\
\hline 2003 & 19.221 & 24.051 & 21.970 & 112.933 & 5.180 & 19.013 & 106.683 & 24.584 & 10.200 & 0.513 & 0.218 & 2.330 & 10.918 \\
\hline 2004 & 30.408 & 29.592 & 21.134 & 114.909 & 9.048 & 18.078 & 102.294 & 25.167 & 18.000 & 2.890 & 0.194 & 2.300 & 9.605 \\
\hline 2005 & 33.741 & 21.260 & 22.585 & 102.119 & 13.570 & 18.635 & 96.996 & 32.197 & 29.000 & 4.375 & 0.205 & 2.500 & 7.603 \\
\hline 2006 & 25.936 & 26.623 & 24.761 & 96.096 & 9.056 & 18.442 & 97.679 & 44.363 & 39.400 & -0.371 & 0.844 & 2.650 & 7.600 \\
\hline 2007 & 33.243 & 31.795 & 26.654 & 95.207 & 12.840 & 18.306 & 97.063 & 58.170 & 78.000 & 0.843 & 0.392 & 2.850 & 5.779 \\
\hline 2008 & 26.801 & 25.292 & 27.940 & 101.834 & 25.232 & 16.996 & 96.051 & 88.378 & 14.000 & 3.103 & 0.404 & 2.850 & 7.544 \\
\hline 2009 & -34.581 & -11.801 & 17.060 & 94.425 & 15.895 & 20.147 & 94.936 & 90.573 & 15.000 & 6.756 & 4.905 & 2.850 & 7.102 \\
\hline 2010 & 16.834 & 5.282 & 19.565 & 104.311 & 9.379 & 20.329 & 95.091 & 78.412 & 28.000 & 5.479 & 4.365 & 2.850 & 5.313 \\
\hline 2011 & 20.032 & 4.013 & 22.437 & 106.242 & 7.960 & 17.362 & 93.250 & 71.075 & 16.000 & 3.474 & 1.054 & 3.443 & 8.049 \\
\hline 2012 & 8.002 & 12.540 & 21.716 & 104.093 & 0.556 & 18.650 & 97.106 & 69.579 & 13.000 & 2.945 & 0.914 & 3.443 & 5.431 \\
\hline 2013 & 3.394 & 8.000 & 18.094 & 96.101 & -0.276 & 18.428 & 98.350 & 74.264 & 13.200 & 4.801 & 1.408 & 3.443 & 5.872 \\
\hline 2014 & -23.107 & -6.614 & 14.078 & 102.395 & 12.188 & 18.593 & 99.237 & 76.198 & 11.700 & .097 & 1.523 & 3.443 & 5.618 \\
\hline 2015 & -31.000 & -25.779 & 15.317 & 107.532 & 48.724 & 19.036 & 99.270 & 56.969 & 9.500 & 4.392 & 1.638 & 3.443 & 8.812 \\
\hline
\end{tabular}

Source: calculated by the authors according to [http://ukrstat.gov.ua; http://data.worldbank.org; https://bank.gov.ua; http://tradingeconomics.com; http:// ebrd.com] 
Table 6. Correlation matrix. Results of calculated correlation of dependent and independent variables of regression model of the relationship between economic growth and financial development for Ukraine

\begin{tabular}{|c|c|c|c|c|c|c|c|c|c|c|c|c|c|}
\hline $\mathrm{V}$ & G_realGDP & G_realGNI & $G C F$ & $T$ & Infl & GFCE & GER & $D C$ & $M C$ & $N I L \_d$ & $N I L \_f$ & $F I D$ & IRS \\
\hline$G \_$realGDP & 1 & & & & & & & & & & & & \\
\hline G_realGNI & 0.893 & 1.000 & & & & & & & & & & & \\
\hline$G C F$ & 0.186 & 0.069 & 1.000 & & & & & & & & & & \\
\hline$T$ & 0.320 & 0.337 & -0.668 & 1.000 & & & & & & & & & \\
\hline Infl & -0.212 & -0.302 & 0.660 & -0.768 & 1.000 & & & & & & & & \\
\hline GFCE & -0.198 & -0.253 & -0.241 & -0.073 & -0.310 & 1.000 & & & & & & & \\
\hline GER & 0.248 & 0.330 & -0.481 & 0.704 & -0.360 & -0.300 & 1.000 & & & & & & \\
\hline$D C$ & 0.084 & 0.249 & -0.354 & 0.281 & -0.304 & -0.410 & 0.094 & 1.000 & & & & & \\
\hline$M C$ & 0.534 & 0.626 & 0.048 & 0.118 & -0.210 & -0.231 & 0.041 & 0.393 & 1.000 & & & & \\
\hline NIL_d & -0.189 & -0.096 & -0.533 & 0.276 & -0.215 & -0.260 & 0.100 & 0.778 & 0.061 & 1.000 & & & \\
\hline$N I L f$ & -0.423 & -0.379 & -0.058 & -0.310 & 0.160 & 0.067 & -0.460 & 0.442 & 0.004 & 0.552 & 1.000 & & \\
\hline FID & 0.145 & 0.269 & -0.621 & 0.541 & -0.524 & -0.280 & 0.248 & 0.850 & 0.366 & 0.658 & 0.150 & 1.000 & \\
\hline $\operatorname{IRS}$ & -0.397 & -0.541 & 0.419 & -0.450 & 0.341 & 0.452 & -0.467 & -0.823 & -0.507 & -0.631 & -0.108 & -0.791 & 1 \\
\hline
\end{tabular}

Source: calculated by the authors. 
Table 7. Correlation matrix. Results of calculated correlation of dependent and independent variables of regression model of the relationship between economic growth and financial development indices for Ukraine

\begin{tabular}{|c|c|c|c|c|c|c|c|c|c|c|c|}
\hline & G_realGDP & G_realGNI & $G C F$ & $T$ & Infl & GFCE & $D C$ & $M C$ & $L L$ & FID & IRS \\
\hline$G$ realGDP & 1 & & & & & & & & & & \\
\hline$G$ realGNI & 0.893 & 1.000 & & & & & & & & & \\
\hline$G C F$ & 0.186 & 0.069 & 1.000 & & & & & & & & \\
\hline$T$ & 0.320 & 0.337 & -0.668 & 1.000 & & & & & & & \\
\hline Infl & -0.212 & -0.302 & 0.660 & -0.768 & 1.000 & & & & & & \\
\hline$G F C E$ & -0.198 & -0.253 & -0.241 & -0.073 & -0.310 & 1.000 & & & & & \\
\hline$D C$ & 0.084 & 0.249 & -0.354 & 0.281 & -0.304 & -0.410 & 1.000 & & & & \\
\hline$M C$ & 0.534 & 0.626 & 0.048 & 0.118 & -0.210 & -0.231 & 0.393 & 1.000 & & & \\
\hline$L L$ & -0.314 & -0.230 & -0.395 & 0.058 & -0.080 & -0.152 & 0.731 & 0.044 & 1.000 & & \\
\hline FID & 0.145 & 0.269 & -0.621 & 0.541 & -0.524 & -0.280 & 0.850 & 0.366 & 0.521 & 1.000 & \\
\hline IRS & -0.397 & -0.541 & 0.419 & -0.450 & 0.341 & 0.452 & -0.823 & -0.507 & -0.485 & -0.791 & 1.000 \\
\hline
\end{tabular}

Source: calculated by the authors. 